\title{
EFFECT OF THE APPLICATION OF DRIED SLURRY ON YIELD AND CHEMICAL COMPOSITION OF MAIZE FODDER (Zea mays)
}

\author{
M. R. Islam ${ }^{2}$, S. M. E. Rahman ${ }^{2}$, K. M. S. Islam ${ }^{1}$ and R. Chowdhury ${ }^{1 *}$
}

\begin{abstract}
The experiment was carried out to evaluate the effect of different levels of dried slurry (DS) as source of nitrogen fertilizer on yield and chemical composition of maize fodder (Zea mays). Four levels of DS (0, 10, 12 and 14 ton/ha) were applied in a Randomized Block Design (RBD). Green biomass yields was significantly higher in DS incorporated groups compared to control. The highest $(\mathrm{P}<0.01)$ biomass yield was observed at the application of 12 ton DS/ha. Application of 12 ton DS/ha resulted highest plant height, number of leaves and leaves area $\left(\mathrm{cm}^{2}\right)$ and stem circumference of maize fodder $(\mathrm{P}<0.01)$. Dry matter $(\mathrm{DM})$ and crude protein $(\mathrm{CP})$ content of maize fodder was increased $(\mathrm{P}<0.01)$ with an application of 12 ton $\mathrm{DS} /$ ha while acid detergent fiber (ADF) and total ash contents were decreased with an increased level of DS. Organic matter (OM) and neutral detergent fiber (NDF) content of green grass were non significant for the incorporation of different levels of DS. From the results of the present study it is evident that, maize fodder can be cultivated through the application of 12 ton DS/ha for obtaining higher yield and nutrient content.
\end{abstract}

Key words : Maize fodder, Dried slurry, Nitrogen, Yield, Nutrient content

\section{Introduction}

In Bangladesh organic farming is being followed from ancient time for cultivating the land and increasing crops production in an eco-friendly environment. Livestock and poultry manures as organic fertilizer increase soil fertility as well as crop or fodder yield and reduce environmental pollution. Slurry is one of the potential sources of soil nutrients for small holder rural farmers. It contains 13, 9.2 and $4.8 \mathrm{lbs} / 1000$ gallons nitrogen $(\mathrm{N})$, potassium $(\mathrm{K})$ and phosphorus (P) respectively (Zhang, 2003). Mikled et al. (2002) stated that application fermented slurry (FS) (by product of anaerobic fermentation of animal excreta in biogas digester) in land significantly increased baby corn yield, corn Stover yield and nutritive value. Patel and Patel (1992) reported that application of FS significantly increase green forage, DM and CP yield of sorghum forage.

Fertilizer especially nitrogen $(\mathrm{N})$ has profound effects on the yield and nutritive value of maize fodder (Hamid et al., 1985). Positive effective of $\mathrm{N}$-fertilizer on maize fodder both in

\footnotetext{
${ }^{1 *}$ Corresponding author. M. S student, Department of Animal Nutrition, Bangladesh Agricultural University, Mymensingh-2202, Bangladesh. Email: rakhich03_bau@yahoo.com

${ }^{2}$ Department of Animal Science, Bangladesh Agricultural University, Mymensingh-2202, Bangladesh
}

(Received : December 31, 2008) 
Bang. J. Anim. Sci. 2008, 37(2)

quality and quantity yield was reported by Gonet and Stadejek (1992); Hammam (1995) and Khandaker and Islam (1988). In Bangladesh, unplanned cultivation of land is the first reason of soil fertility reduction which leads to using overdose chemical fertilizer in soil. Every year farmers face a critical situation for the crisis of nitrogen fertilizer and also for its high price. Efficient use of organic fertilizer can overcome this situation. The addition of organic matter via slurry might be useful to conserve soil fertility by increasing organic matter, which is decomposed slowly but steadily. It helps to maintain soil fertility and hold suitable $\mathrm{pH}$ of soil for better fodder production. It is also available and cheap. Therefore, the present experiment was undertaken to study the effect of dried slurry as nitrogen fertilizer on yield and chemical composition of maize fodder.

\section{Material and Methods}

The experiment was conducted in the fodder plot of Sheep, Goat and Horse farm, Bangladesh Agricultural University, Mymensingh using different levels of dried slurry (DS). The land was flat, moderate drained and above flood levels. The soil was silt loam textured, neutral in reaction $(\mathrm{pH}=7)$. The average soil nutrient contents were $0.140 \%, 0.114 \%, 0.411$ $\mathrm{ppm}$ and $0.110 \mathrm{ppm}$ for nitrogen, phosphorus, potassium and sulfur respectively. The land was well prepared by traditional ploughing and was leveled by subsequent harrowing and laddering. The land was divided into 12 plots each having $10 \mathrm{~m}^{2}(4 \mathrm{~m} \times 2.5 \mathrm{~m})$ following Randomized Block Design (RBD).

The experimental treatments were designed as control $\left(\mathrm{T}_{0}\right)$, DS 10 ton/ha $\left(\mathrm{T}_{1}\right)$, DS 12 ton/ha $\left(\mathrm{T}_{2}\right)$ and DS 14 ton/ha $\left(\mathrm{T}_{3}\right) .10$ ton DS supplied $14.7 \mathrm{~kg} \mathrm{~N} / \mathrm{ha}, 10 \mathrm{~kg} \mathrm{~K} / \mathrm{ha}$ and $5.4 \mathrm{~kg} \mathrm{P} / \mathrm{ha} ; 12$ ton DS supplied $17.6 \mathrm{~kg} \mathrm{~N} / \mathrm{ha}, 12 \mathrm{~kg} \mathrm{~K} / \mathrm{ha}$ and $6.5 \mathrm{~kg} \mathrm{P} / \mathrm{ha}$ and 14 ton DS supplied $20.5 \mathrm{~kg}$ $\mathrm{N} / \mathrm{ha}, 14 \mathrm{~kg} \mathrm{~K} / \mathrm{ha}$ and $7.5 \mathrm{~kg} \mathrm{P} / \mathrm{ha}$. Triple super phosphate (TSP) and murate of potash (MP) at the rate of $60 \mathrm{~kg} / \mathrm{ha}$ and $40 \mathrm{~kg} / \mathrm{ha}$ respectively were applied as a basal dose at the time of land preparation and DS was applied at the time of final preparation of land. Seeds were sown in rows at the rate of $55 \mathrm{~kg} /$ ha with arrow spacing of $30 \mathrm{~cm}$ and plant spacing of $15 \mathrm{~cm}$. Biomass yield and plant characteristics such as plant height, number of leaves and area of leaves were measured in this study. The maize plants were harvested after 56 days and fresh biomass yield from each plot was recorded. Representative samples during the harvesting of the plants were collected from each plot. The samples were chopped, dried in the sun, ground and kept in the polythene bags and stored for further analysis. At the same time freshly collected samples from each plot were kept for determining dry matter content of fresh forage. The chemical components (DM, CP and Ash) were determined according to the method of AOAC (1990). Acid detergent fiber (ADF) and neutral detergent fiber (NDF) were estimated by the methods of Faichney and white (1983).

The data were analyzed statistically by using 'MSTAT' statistical program to compute analysis of variance (ANOVA) in a Randomized Block Design. Differences among the treatment means were determined by Duncan's Multiple Range Test (Gomez and Gomez, 1984). 


\section{Results and Discussion}

\section{Yield and plant characteristics}

The yield and plant characteristics of maize fodder cultivated at different levels of DS as nitrogen fertilizer in respect of green biomass, number of leaves, leaves area $\left(\mathrm{cm}^{2}\right)$, plant height and stem circumference are shown in Table 1 . The green biomass yield at the rate of $0,10,12$ and 14 ton DS/ha were 34.6, 45.0, 54.0 and 42.7 respectively. Highest $(\mathrm{P}<0.01)$ biomass yield was observed in application of 12 ton DS/ha compared to control, 10 and 14 ton DS/ha. Although application of 10 and 14 ton DS/ha resulted higher biomass yield than control but statistically there was no significant difference between without DS and 14 ton DS/ha. Similarly non significant difference was observed between 10 and 14 ton DS/ha.

Table 1. Yield and plant characteristics of maize fodder at different levels of dried slurry as nitrogen fertilizer

\begin{tabular}{|c|c|c|c|c|c|c|}
\hline \multirow{2}{*}{ Parameters } & \multicolumn{4}{|c|}{ Treatments $^{\#}$} & \multirow{2}{*}{ SEM } & \multirow{2}{*}{$\begin{array}{l}\text { Level of } \\
\text { sig. }\end{array}$} \\
\hline & $\mathbf{T}_{\mathbf{0}}$ & $\mathbf{T}_{1}$ & $\mathbf{T}_{2}$ & $\mathbf{T}_{3}$ & & \\
\hline \multicolumn{7}{|l|}{ Yield } \\
\hline Biomass (MT/ha) & $34.6^{\mathrm{c}}$ & $45.0^{\mathrm{b}}$ & $54.0^{\mathrm{a}}$ & $42.7^{\mathrm{bc}}$ & 2.20 & $* *$ \\
\hline \multicolumn{7}{|l|}{ Plant Characteristics } \\
\hline Plant height (cm) & $226.7^{\mathrm{d}}$ & $243.8^{\mathrm{c}}$ & $258.6^{\mathrm{a}}$ & $247.0^{\mathrm{b}}$ & 3.50 & $* *$ \\
\hline Stem circumference $(\mathrm{cm})$ & $7.9^{\mathrm{c}}$ & $8.9^{\mathrm{b}}$ & $9.3^{\mathrm{a}}$ & $8.38^{\mathrm{b}}$ & 0.19 & $* *$ \\
\hline Number of leaves & $12.9^{\mathrm{c}}$ & $14.5^{\mathrm{b}}$ & $15.8^{\mathrm{a}}$ & $13.6^{\mathrm{bc}}$ & 0.36 & $* *$ \\
\hline Leaves area $\left(\mathrm{cm}^{2}\right)$ & $391.1^{\mathrm{d}}$ & $485.9^{\mathrm{b}}$ & $533.8^{\mathrm{a}}$ & $447.3^{\mathrm{c}}$ & 0.05 & $* *$ \\
\hline
\end{tabular}

${ }^{\#} \mathrm{~T}_{0}=$ without dried slurry (DS); $\mathrm{T}_{1}=10$ ton DS/ha; $\mathrm{T}_{2}=12$ ton DS/ha and $\mathrm{T}_{3}=14$ ton DS/ha SEM, standard error of mean; ** $\mathrm{P}<0.01$

abc mean values with dissimilar superscripts differ significantly

The application of DS increased the availability of soil nitrogen, which might have enhanced the growth and resulted higher biomass yield. This result is coincide with the findings of Patel and Patel (1992) who reported higher green forage (sorghum) yield with an application of FS (fermented slurry) in land. Application of DS resulted significantly $(\mathrm{P}<0.01)$ higher number of leaves and leaves area $\left(\mathrm{cm}^{2}\right)$ compared to without DS. It is indicated that, 12 ton DS /ha significantly $(\mathrm{P}<0.01)$ increased number of leaves and leaves area $\left(\mathrm{cm}^{2}\right)$ compared to others treatments. These results are in agreement with the findings of Chen et al. (1994) who observed that, application of nitrogen fertilizer significantly increased number of leaves, its length, thickness and width of maize fodder. It is apparent that, plant height and stem circumference of maize fodder in the present experiment were significantly $(\mathrm{P}<0.01)$ increased at the application of different level of DS. Highest $(\mathrm{P}<0.01)$ plant height and stem circumference were observed in 12 ton DS/ha incorporated group. This result is in accordance with Hammam (1995) who reported that, application of different level of nitrogen fertilizer increased plant height as compared to control. 
Bang. J. Anim. Sci. 2008, 37(2)

\section{Chemical composition}

Chemical composition of maize fodder $(\mathrm{g} / 100 \mathrm{~g} \mathrm{DM})$ cultivated under different levels of DS is shown in Table 2. The highest $(\mathrm{P}<0.05) \mathrm{DM}$ content was observed from the application of 12 ton DS/ha followed by 10, 14 ton DS/ha and without DS. The results indicated that application of slurry as nitrogen fertilizer increase DM content of maize fodder. Significantly higher DM content of forage crop with application of FS (fermented slurry) in land was reported by Mikled et al. (1994). Gonet and Stadejek (1992) stated that average DM content of maize fodder increased with an application of nitrogen fertilizer. Although DS treated groups showed numerically higher OM content than control group but there was no significant difference among the treatments.

The CP contents were found to be 9.9, 10.6, 11.9 and $10.4 \mathrm{~g} / 100 \mathrm{~g}$ DM by the application of $0,10,12$ and 14 ton DS/ha respectively. Application of different levels DS significantly $(\mathrm{P}<0.05)$ increased CP content of maize fodder. This might be due to rapid synthesis of carbohydrates into protein and protoplasm leaving relatively smaller portion for cell wall synthesis. Twelve ton DS/ha resulted highest CP content of maize fodder. Beckwith et al. (2002) found that application of organic manure increased the CP content of cut grass.

Table 2. Chemical composition (g/100g DM) of maize fodder at different levels of dried slurry as nitrogen fertilizer

\begin{tabular}{|c|c|c|c|c|c|c|}
\hline \multirow{2}{*}{ Composition } & \multicolumn{4}{|c|}{ Treatments ${ }^{\#}$} & \multirow{2}{*}{ SEM } & \multirow{2}{*}{$\begin{array}{l}\text { Level of } \\
\text { Sig. }\end{array}$} \\
\hline & $\mathbf{T}_{\mathbf{0}}$ & $T_{1}$ & $\mathbf{T}_{2}$ & $\mathbf{T}_{3}$ & & \\
\hline $\mathrm{DM}(\mathrm{g} / 100 \mathrm{~g}$ green fodder $)$ & $19.3^{\mathrm{b}}$ & $19.8^{\mathrm{b}}$ & $21.3^{\mathrm{a}}$ & $19.7^{\mathrm{b}}$ & 0.27 & $*$ \\
\hline \multicolumn{7}{|l|}{ On DM basis } \\
\hline $\mathrm{OM}$ & 92.5 & 92.9 & 92.9 & 93.1 & 0.31 & NS \\
\hline $\mathrm{CP}$ & $9.9^{c}$ & $10.6^{\mathrm{b}}$ & $11.9^{\mathrm{a}}$ & $10.4^{\mathrm{b}}$ & 0.25 & * \\
\hline $\mathrm{ADF}$ & 35.3 & 34.9 & 34.8 & 33.3 & 0.38 & NS \\
\hline $\mathrm{NDF}$ & 55.6 & 56.4 & 57.6 & 55.8 & 0.32 & NS \\
\hline Total Ash & $7.5^{\mathrm{a}}$ & $7.1^{\mathrm{b}}$ & $7.1^{\mathrm{b}}$ & $6.9^{\mathrm{c}}$ & 0.32 & $*$ \\
\hline
\end{tabular}

${ }^{\#} \mathrm{~T}_{0}=$ without dried slurry (DS); $\mathrm{T}_{1}=10$ ton $\mathrm{DS} / \mathrm{ha} ; \mathrm{T}_{2}=12$ ton $\mathrm{DS} /$ ha and $\mathrm{T}_{3}=14$ ton DS/ha

$\mathrm{SEM}$, standard error of mean; NS = non significant; $* \mathrm{P}<0.05$

${ }_{\text {abc }}$ mean values with dissimilar superscripts differ significantly

The ADF content of maize fodder decreased due to increased levels of DS (Table 2). This could be due to slower rate of synthesis plant cell wall components (lignin and cellulose) as in the $\mathrm{N}$ level was increased due to increased level of DS from 0 to 14 ton/ha. There is a positive relationship between nitrogen fertilization and increased vegetative growth of plants with a concomitant decrease in cell wall parts. The result is in keeping with the findings of Ramanurthy and Shivashankar (1996). They reported that, application of organic waste decreased ADF content of maize fodder. There was no significant difference in NDF content among the treatments. The highest NDF content was found in 12 ton DS/ha treated group 
and lowest in control group. Total ash content of maize fodder decreased significantly with increased level of DS. The result is similar with the report of Khan et al. (1996) who stated that, application of nitrogen fertilizer decreased ash content of oat fodder.

\section{Conclusion}

It may be concluded that maize fodder harvested at 56 days of age through application of 12 ton DS/ha was best for biomass yield and nutrient contents. So, dried slurry might be an important source of organic fertilizer which can increase soil fertility by increasing organic matter as well as crop or fodder yield and reduce environmental pollution.

\section{Literature Cited}

AOAC, 1990. Official Methods of Analysis (15 $5^{\text {th }}$ ed.). Association of Official Analytical Chemists. Washington DC.

Beckwith, C. P., Chalmers, A. G., Lewis, P. J., Forment, M. A. and Smith, K. A. 2002. Successive annual application of organic manure cut grass: Short-term observation on utilization of manure nitrogen. Grass and Forage Sci., 57(3) : 191-202.

Chen, H. Y., Zhang, J. H., Jing, X. L. and He, Y. H. 1994. Effect of nitrogen on yield and leaf structure in pop corn. J. Shanghi Agril. College, 12 (4) : 253-256.

Faichney, G. J. and White, G. A. 1983. Methods for the analysis of feeds eaten by ruminants. Com. Sci. and Inds. Res. Org. Australia.

Gomez, K. A. and Gomez, A. A. 1984. Statistical procedure for Agricultural Research. Int. Rice Res. Inst. John Wiley and Sons. New York, Ckickerster, Brisbane, Toronto, Singapore, pp. 139-240.

Gonet, Z. and Stadejek, H. 1992. Effect of nitrogen fertilizer application on yield and feeding value of maize shown at high plant density for green forage. Zaklad, pryrodniczych Pod Straw Zmian Owania, Roslin, IUNG, Poulaway, Poland, pp. 22-25.

Hamid, M. A., Hossain, S. A., Khatun, F., Das, U. R. and sultan, K. 1985. Maize research and development project annual report. Bangladesh Agric. Res. Ins., Joydebpur, Gazipur, Bangladesh.

Hammam, G. V. 1995. Effect of nitrification inhibitor and nitrogen level on growth and yield of maize. Annals. Agril. Sci. Moshtohor, 33(2) : 495-506.

Khan, M. J., Shahjalal, M. and Sarker, A. R. 1996. Yield, chemical composition and nutritive value of oat fodder at different levels of nitrogen fertilization. Bangladesh J. Anim. Sci., 25(1-2) : 109-115.

Khan, M. J., Tareque M. M. and Islam, M. M. 1995. Effect of nitrogen and phosphorus fertilizer on maize fodder grow in various row widths and inter row spacing. Bangladesh J. Agril. Sci., 22 (1) : 165-170.

Khandaker, Z. H. and Islam, M. M. 1988. Effect of nitrogen fertilization and stage of maturity on yield and quality of maize (Zea mays). Bangladesh J. Anim. Sci., 17(1-2) : 47-53. 
Bang. J. Anim. Sci. 2008, 37(2)

Mikled, C., Jiraporncharoen, S. and Potikanond, N. 1994. Fermented slurry as fertilizer for the production of forage crops. Final Report, Thai- German Biogas Program.

Mikled, C., Jiraporncharoen, S. and Potikanond, N. 2002. Utilization of fermented slurry as biofertilizer. Proceddings of Bio-digester workshop, March, 2002.

Patel, R. S. and Patel J. R., 1992. Effect of zinc with and without Farmyard manure on production and quality of forage sorghum. Ind. J. Agron., 37(4) : 729-735.

Ramanurthy, V. and Shivashankar, K. 1996. Residual effect of organic matter and phosphorus on growth, yield and quality of maize (Zea mays). Indian J. Agron., 41(2) : 247-249.

Zhang, H. 1985. Economics of producing corn maize and sorghum as feeds for animal production in China. Proc. of the $15^{\text {th }}$ Int. grass Society Congress, Kyoto, Japan, pp. 1229-1231.

Zhang, H. 2003. fertilizer nutrients in animal manure. Oklahoma Cooperative Extension Service. USA. 